\title{
Indonesian Case of Political Identity, Post Truth, and Computational Propaganda
}

\author{
Fajar Cahyono ${ }^{1}$, Kusuma Putri, Hafizh Nurul Faizah \\ ${ }^{a}$ Universitas Gadjah Mada, Jl. Olahraga, Caturtunggal, Depok, Karang Malang, Caturtunggal, Kec. Depok, Kabupaten Sleman, Daerah Istimewa \\ Yogyakarta 55281 \\ 1fajar.cahyono97@gmail.com
}

\section{ARTICLE INFO}

\section{Article history}

Received 2 September 2019

Revised 15 October 2019

Accepted 30 October 2019

Keywords

Computational Propaganda; Political Identity; Social Media

\section{ABSTRACT}

The purpose of this study is to investigate the use of Computational Propaganda in organizing and manipulating public opinion on social media through the issue of identity politics in the 2019 Indonesian Presidential Election. There are two methods used in this study namely qualitative method to answer the effectiveness of the use of Computational Propaganda for campaigns in the 2019 Presidential Election, and quantitative method to measure and identify the use of Computational Propaganda during the campaign period through the big software Emprit Drone data. This study found that the use of political identity issues and Computational Propaganda were structured and organized. The manipulation of public opinion through calculated selection of issues and online popularity produced a false consensus with the aim of gaining political support from the public

This is an open access article under the CC-BY-SA license

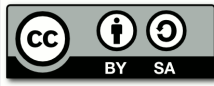

\section{Introduction}

This research explains in detail about the use of organized technology in social media as a political campaign in the 2019 Presidential Election. The topic is important because, in recent years, there has been a shift in the use of social media as a "primary medium" for political campaigns. As far as observation goes, research that discusses the use of organized technology on social media is limited to just revealing the facts and impacts occurred in the field. Therefore, this research will focus on providing an explanation of the use of political identity to manipulate public opinion on social media.

Based on the report of We are Social and Hootsuite (wearesocial.com), of the total world population of around 7.676 billion, almost half are active social media users. Indonesia, with a total population of around 268.2 million people, has around 150 million internet users (13\% increase from 2018); active social media of 150 million people (15\% increase from 2018); and 130 million mobile social media ( $8.3 \%$ increase from 2018$)$.

Social media users in Indonesia are also predicted to increase sharply every year, given the completion of the Palapa Ring project in 2019. Improved infrastructures in the telecommunications network will open inclusive internet access to remote areas. This increase of internet access will also result in the increased use of social media. The use of social media which continues to increase every year creates a potential for this particular platform as new communication space for its users. The characteristics of the social media that are not limited to space and time make it comparably more valuable than other communication media.

The victory of Jokowi in DKI Jakarta Election remarked one of the new eras in political marketing [1]. The strategy used by the Jokowi team is relatively new due to the use of social 
media as a platform to convey ideas. The DKI's 2012 election opened our eyes to see the phenomenon of Domestication of Technology in political campaigns.

Trends in the use of social media as a tool for communication and political propaganda have recently been on the rise. Cases such as the 411 action, 212 action, the 2017 DKI Pilkada, 2019 Presidential Election, students action in rejecting the RUU KPK cannot be separated from the role of social media as a propaganda medium. With the increasing role of social media this propels the creations of digital community or enthusiasts such as JASMEV (Jokowi-Ahok Social Media Volunteer), MCA (Muslim Cyber Army), and many more. The emergence of the use of social media as a medium in campaigning for ideas cannot also be left separable from new problems that arise with it.

This research explores the use of digital technology through social media as a medium of political propaganda and the use of identity politics issues in the 2019 presidential election campaign. This research was chosen since a massive wave of political campaigns was carried out on social media and this has caused many problems. MAFINDO notes that political hoax is the biggest contributor to the overall cumulative hoax that exist on social media. An issue that had recently risen was a Give Away tweet given by an account with a specific hashtag to increase conversation volume. The use of social media as a step to manipulate public opinion is the definition of Computational Propaganda [2].

Computational Propaganda can also be interpreted as a form of transformation from classical propaganda that meets the massive development of the internet. Computational Propaganda utilizes the results of interpretations of big data released in the form of analysis of community preferences. Big data on the internet is available on paid (Facebook, Instagram, Youtube, etc.) or free (Twitter) social media platforms. The possibility of accuracy of propaganda on a small or large scale will be higher with visible community preferences that are grouped into region, issues, hobbies, preferences, and so forth.

Technology, in this case social media, yields its role through human assistance in creating false consensus that removes awareness of individuals. Social media is mishandled in its role in becoming a new public space due to the entry of certain interests through the use of big data. A pleasant, gentle, sensible, and democratic freedom is applicable in advanced industrial civilizations [3]. Choice of issues in regards to identity politics cannot be overlooked and taken out of the equation of strategy to gain mass attention. Within Indonesia, as a country consisting of very diverse backgrounds and entities, the issues surrounding identity become a topic that is often used.

Based on the conditions mentioned, this study aims to find out how political propaganda that utilizes social media influences the intended target. Additionally, this study also aims to determine the extent of public attention and effects of identity politics used in the selection of issues to attack opposing sides or defend its own.

This study is assembled from quantitative data collection using the Drone Emprit big data software from social media platforms. Literatures and interview with one of the digital campaign consultants were also used to compose this research. This research will explain how the use of social media as a medium for political campaigns, especially the involvement of bots and the use of identity politics issues are used to carry out political propaganda. The discussions will be focused on the 2019 Presidential Election campaign.

\section{Method}

This research is established through mixed methods research. This research combined two forms of research, which are qualitative and quantitative methods. Mixed methods approach is a mixture of qualitative and quantitative research methods. Sugiyono (2011) said the combination research method would be useful when qualitative and quantitative methods were not accurate enough to be used to understand the research problem. In other words, the commencement of the use of combination research is based on the weaknesses of each research method, both qualitative and quantitative, if it stands alone. 
This study uses a sequential mixed-method strategy which is a strategy for combining data. Quantitative data collection by data mining on Twitter social media and visualization through Social Network Analysis (SNA) charts from retweet conversations on Twitter. The sample is used purposively (sampling with the aim of capturing as much information as possible). There are sample criteria taken with the aim of getting the desired data. The sample criteria used are \#2019GantiPresiden \#2019TetapJokowi, Prabowo, Jokowi, Koran Test and other issues that are still related to the presidential election. Retrieval of qualitative data was employed, by conducting library methods and expert interviews

\section{Results and Discussion}

Propaganda comes from the Latin word propagare (verb) which means to spread, sprinkle, and breed. The word propaganda is also closely related to the branch of biology to describe the activity of increasing plant populations that can be done by seedlings, by cutting or cutting, grafting. In the Indonesian Encyclopedia the word propaganda means expansion.

The word propaganda was first used by Pope Gregory to XV to discuss religious teachings. "Sacra Congregatio de Propaganda Fide" or "Sacred Congregation for Propagation of the Faith". The use of the term propaganda also occurred in the first world war.

In 1927 Harold Lasswell published his dissertation into a book entitled Propaganda technique in The World War. Lasswell saw and supported the propaganda carried out by two camps in the first world war. Lasswell's writings received much public attention. Unfortunately, most people and opposing facts view propaganda techniques in the first world war.

According to Encyclopedia International, propaganda is a type of communication that seeks to influence views and reactions, without the need to care about the true or incorrect value of the message being conveyed. While the view is almost similar from Encyclopedia Everyman's propaganda is an art to spread and convince a belief. Propaganda gives a message without the need for further explanation of the in-depth reasons for the message. In addition, propaganda messages that tend to be short make it easy for recipients to understand them. Thus, propaganda is a potential medium to be used to spread messages.

Propaganda also has several types, namely white, black, and gray [4]. First, white propaganda is the spread of ideas that are done honestly, correctly, and sportsmanship. Second, black propaganda is propaganda that is rolled out to trick, cheat, be full of falsehood, and disregard ethics. And third, gray propaganda that is a propaganda carried out by individuals or groups with unclear sources.

The history of the propaganda medium is somehow always related to space and time. In the Hitler era, propaganda was packaged through pamphlets which were then distributed to the public. Moving nearly a century after Hitler, Donald Trump used the internet to campaign for him, who had a fruitful victory in the 2016 US Presidential election. However, each form of propaganda has different characteristics. That way, the results and strategies used are also different.

The internet came into existence in the late 20th century which allowed a number of networks to be connected to each other that transcended boundaries of space and time. In the 21st century the internet has become more advanced and access to use it has become more open. One form of internet progress in terms of communication is social media. The characteristics of social media allow each user to not only consume information, but also produce information while distributing the information. Today social media is the main medium in which humans communicate, making one of the forms of the internet an effective tool for use as a propaganda medium.

Social media is now organized in such a way as to generate false awareness for the public. The information in social media is no longer a busy space that is free from certain agendas. This phenomenon is also known as Computational Propaganda [5]. Computational Propaganda is part of the sociotechnical phenomenon. 
Technically, it is defined as a collection of social media platforms, autonomous agents, and big data assigned to manipulate public opinion. In contrast, the social definition of computational propaganda comes from the definition of propaganda; communication that intentionally depicts symbols, appeals to emotions and prejudices and passes through rational thinking, to achieve the specific objectives of its creatorsComputational Propaganda also occurs in countries other than the US. Jeman [6], Russia [7] and 28 other countries are a handful of Computational Propaganda phenomena in the 2010-2017 time span [8]. No exception in Indonesia. A research revealed that the two pairs of candidates for President of the Republic of Indonesia were proven to use bots in playing the hashtags \#01IndonesiaMaju and \#2019GantiPresiden on twitter [9].

Technology in this case the internet takes its role with human assistance in creating false consensus that removes awareness from individuals. In this case, the role of the Internet is doubted as a new public space, due to the entry of certain interests through the use of big data. An unpleasant, gentle, sensible, and democratic freedom is applicable in advanced industrial civilizations [3].

\section{Digital Era of Democracy}

The current era seems to facilitate all human activities, including the implementation of democratic governance. E-democracy or digital democracy is present as a consequence of today's development. The discussion of digital democracy is divided into several keywords, such as the relation of cyberspace (online) and the real world (offline); representation and participation; and netizens. First, the relation of cyberspace (online) and the real world (off-line) plays an important role in the construction of critical public political reasoning that seeks and competes to form networks based on the same issues and interests to form a movement. Secondly, representation and participation are the principles of digital democracy today, which in essence calls for openness and public accessibility to government. Third, netizens are public as users or receivers of various information through their respective social media accounts. Finally, digital democracy creates political imaginations and ideal democracies according to citizens formulated through cyberspace as new public spaces. The function of social media with the middle class public on political issues is because the internet creates a sense of space, a sense of real, or a sense of belonging. The existence of these three sensations is what drives the massive and intense use of social media among the middle class. Virtual space is able to reflect itself in actual space reciprocally, so that communication in cyberspace also impacts on real communication and vice versa. Unfriend, unshare or unfollow actions on social media affect the pattern of interaction in the real world [10].

In this digital democracy, the transformation of democracy becomes closer, real and easily accessible to the people who directly create demos. Cyber community or commonly referred to as netizens, will carry out activities of posting, sharing, like, and commenting on a matter that refers to their political preferences. Thus the role of social media is very strong in shaping a society that is aware of democracy but through digital media. In addition, public participation also increases with the increasing number of netizens who continue to show their political expression in terms of democracy.

The increase in community participation in democracy certainly has implications for the form of democracy that looks more connective, because it is more developing the network than the nature of the previous democracy which is more organic. Seeing the current Indonesian people who tend to see democracy as something informal, populist and multilateral so that it is easy to express easily through posting on social media that they have. And that is also supported by the current era, namely post truth which is able to shift the meaning of democracy which was originally normative, elitist and ceremonial. Due to the very broad access to information currently giving two roles in society at the same time, namely a support group that has many interests or becomes an opposition group whose function is to suppress any existing political discourse either directly or indirectly. 
The challenge that arises with the convenience of digital democracy is the creation of a situation for colliding discourse on social media. Discourse or issues that have taken place in a country will be very easy to compete in the digital world of society, especially social media. Fragmented society as a consequence of this post-truth era will continue to anesthetize the situation so that it creates a conflict of discourse by the parties concerned, especially in the struggle for power. This can be seen in discussions that occur on social media, which in the public sphere there are no more restrictions therein. Discourse that clash with each other, the dissemination of information that is very easy and fast will certainly have implications for public opinion, because the battle between different discourses will affect the social pattern of society in responding to a problem. With the ease of access to social media such as Twitter, WhatsApp, Line and others will be prone to be misused to spread hoax content, hate speech, threats, and black propaganda that clash with each other in the social media arena. This is a crucial challenge in digital democracy, when people are interconnected and networked, it will be very easy to influence the development of democracy itself.

\section{Politics of Identity}

Politics of identity is another name for biopolitics and politics of difference. Biopolitics bases itself on differences arising from bodily differences. While identity according to Jeffrey Week is related to belongin about equality with a number of people and what distinguishes one person from another. Jeffrey's opinion emphasizes the importance of identity for each individual or for a group or community [11]. Whereas Agnes Haller takes the definition of identity politics as a political concept and movement whose focus is on differences as a major political category. After the failure of the big narrative, the idea of difference has promised freedom, tolerance and freedom of play.

Political identity itself is a new concept in the study of political science. In actual philosophy this discourse has long appeared, but its application in the study of political science came to the fore after being sympathized at an International meeting of the Political Scientists Association in Vienna in 1994. The meeting produced a conception of the basics of the practice of identity politics and made it a study in the field of political science .

Our current social political dynamics are in the post-truth era or the post-truth era. Social media has become the most promising means for conducting political campaigns in order to seek support from the public. Society unconsciously invited to put forward their emotional and irrational.

Post truth succeeded in eliminating a healthy political culture where it should be necessary upheld and become very crucial in democratic countries, including Indonesia. In this post truth era the development of identity politics has become easier. With the politics of identity, the public does not care anymore about rational matters in politics. In the case of elections, where the standards we need to look at the overall work program carried by the candidates, the vision and mission carried, and the plans they convey during the campaign. Smart people naturally put forward their rational by considering some of these things. But due to the presence of identity politics, rationality regarding vision and mission, as well as program campaigns have been displaced by bringing personal identities such as religion, ethnicity, and race.

In his writings on identity politics in Indonesia, Habibi explained that Klaus Von Beyme analyze the character of the identity movement in several stages of its development. Fundamental divisions, tribal groups and nationalities gave rise to political movements thorough. In this case ideological mobilization was initiated by leaders. 
The goal is the usurping and usurping power from one ruler to a new ruler. Then in the modern stage, the movement emerges with a conditional approach, disunity requires resources. source to be mobilized. There is a balance of mobilization from above and participation from below, the role of the leader is no longer dominant and the ultimate goal is the distribution of power. Then in post-modern developments, the emergence of movements the movement originated from its own dynamism, protests arose over a variety of individual opportunities, no single group or fraction was dominant. The pattern of actions and activities based on self-awareness that is autonomous as the final goal

Political identities in Indonesia itself has been going on several times over the past few years. Action 212 became one of the heroes of public opinion that is able to be the cause of identity politics in the political world going forward. Included in the phenomenon of the DKI Jakarta Regional Election, it is alleged that many parties are loaded with identity politics. In the Jakarta case, the importance of identity (ethnic and religious) factors in reading voters is enormous.

In 2014, ethnicity still played an important role in influencing voter behavior in the 2007 Jakarta Election in 2012 and 2012, although the significance was smaller than the education and flood variables. The relationship between ethnicity and choice is very dynamic and depends on the political situation and the timing of the election. In the 2007 local elections, Fauzi Bowo's voice was high in villages that were heavily populated by ethnic Chinese and low in villages that were dominated by ethnic Minangkabau and Sundanese. While in 2012 there were differences in the political map. Fauzi Bowo's voice is strong in areas inhabited by ethnic Betawi, Sundanese and Minangkabau. But it is low in voters who are inhabited by ethnic Chinese and Bataks. A similar study showed the importance of identity politics - in this case religion - as one of the determining factors Anies Baswedan and Sandiaga Uno's victory in the 2017 elections in DKI Jakarta. Anies won in urban villages with a large number of Muslim voters and in densely populated areas. While the votes of Ahok or Basuki Tjahja Purnama, are low in areas with large Muslim voter populations and Ahok votes are high in Jokowi base areas in the 2012 elections.

According to a survey conducted by the Indo Survey and Strategy Institute as conveyed by Tempo voters in Indonesia tend to make their choices based on similarity in religion, ethnicity, and race. The survey was carried out in three different provinces namely West Java, Nusa Tenggara and Banten. As many as 85.3 percent of respondents in West Java stated the similarity of religion as a basis for consideration in the election of the Governor of West Java, 12.8 percent of respondents were not affected, then as much as 2 percent answered they did not know. Whereas for respondents in West Nusa Tenggara, as much as 90 percent of respondents chose the same beliefs as the basis for selecting candidates.

\section{Managing Social Media Teams by Using Computational Propaganda}

Using of Computational Propaganda in Indonesia has been previously identified by the Oxford Internet Institute. Twitter, Instagram, Facebook, WhatsApp, were platforms that have been found to be used in Computational Propaganda used by actors involved, which were political parties and contracting companies.

However, Computational Propaganda in Indonesia did not have sophisticated intelligence yet that could ensure a decent human being [4]. Artificial intelligence was a human-made program for a particular purpose. Computational propaganda that requires intelligence would be increasingly difficult. 
Although it was still not very sophisticated compared to others, Computational Propaganda in Indonesia already has a specific strategy. The strategy used to organize the team and then createed issues or discourses in social media with a structured manner [4]. The division of roles has also been carried out in making the issues.

First, the Opinion Leader has the role of making a particular issue or discourse. Opinion Leader played a role in creating the image of a supported partner or making a negative opinion to his opponent. Opinon Leaders in the context of the 2019 presidential election there was an official account of the presidential candidate pair. Second, Influencers, have a role to translate the issue or discourse created by opinion leaders. Every candidate has influencers, one of them is from artists, community leaders, politicians, religious figures and so on.

Third, Buzzer, this team had a role to amplify and popularize issues that give a positive image to the candidates being promoted. Buzzer also has a duty to attack the opponent's stronghold with a negative campaign, forming a new reality or hoaks. Buzzers were categorized into two, red buzzer and white buzzer. The red buzzer came from the Jokowi-Ma'ruf volunteers working not based on orders that receive incentives, but based on ideological similarities. Many of them are also a fraction of JASMEV 2012 (Jokowi Ahok Social Media Volunteer). While the white buzzer was a subject recruited from bloggers and media activists. They were paid to carry out these activities so they have the obligation to spread the issues that have been provided with the posting schedule that has been set by opinion leaders.

Fourth, followers were social media users in general who were targeted and also could be distributors of issues in the circle of friends. Not much different from the propaganda scheme of party 01, party 02 (Prabowo-Sandi National Campaign Board) also divided the role of propaganda on social media.

\section{Use of Bots in the 2019 Presidential Election Campaign}

One of the most important instruments in Computational Propaganda was the use of bots. Bots were used in the framework of two things, first, creating additional volume of conversation in a short or systematic time to the issues or discourses. Second, attacking the opponent or playing victim. In this study found the use of bots by both pairs of candidates in raising the issues or discourses. Identification was used through two things, there were the interaction rate and Social Network Analysis (SNA).

Figure 1. The SNA Map of \#2019GantiPresiden

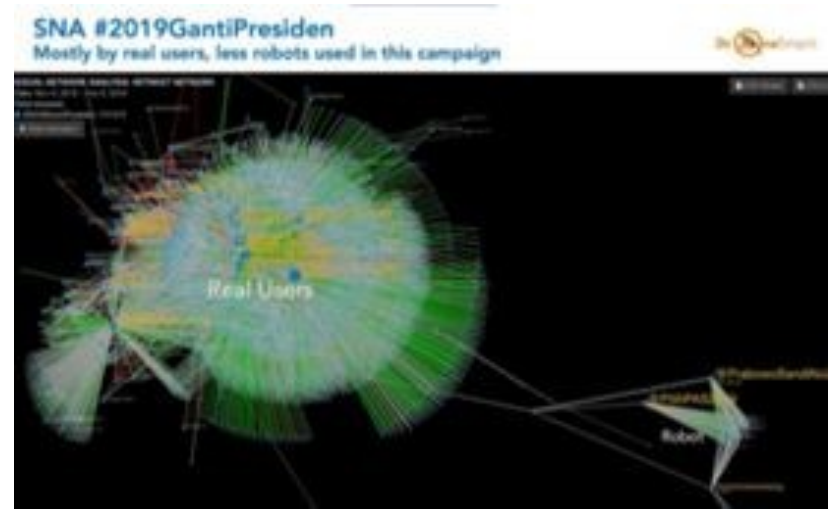

Source: https://pers.droneemprit.id/drone-emprit-dan-g dilab-cyber-troop-jokowi-dan-prabowo 
Social Network Analysis (SNA) hashtag \#2019GantiPresiden in Figure 1 was detected using bots (Fahmi, 2019). In the SNA graph, one large cluster and one small cluster pointing towards the big cluster were seen. One small cluster was identified as bots to help increase the volume of the conversation so that the hashtag becomes a trending topic on Twitter. Prabowo's social media team used more specific issues which shared together with their cyber forces. Unfortunately, the Prabowo's camp brought issues that still impoverished programs and ideas [9].

Social Network Analysis (SNA) hashtag \#01IndonesiaMaju visible one big cluster and there were several small clusters that surround it. A small cluster of lines leads to a large cluster. The small cluster seen on SNA was a bot account used by Jokowi's camp to increase the volume of conversation. This was supported by accounts that only have a small following that produce tweets with the hashtag \#01IndonesiaMaju. According to Ismail Fahmi, the contributing bots only has no more than fifty followers.

Figure 2. The SNA Map of \#01IndonesiaMaju

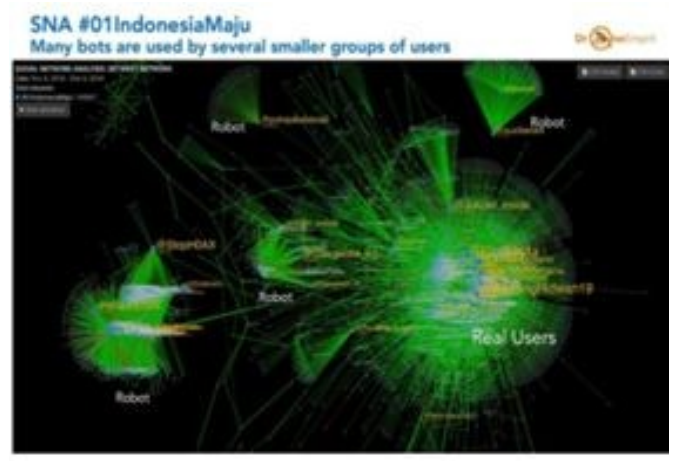

Source: https://pers.droneemprit.id/drone-emprit-dan-g dilab-cyber-troop-jokowi-dan-prabowo/

\section{Stages of Creating New Realities in 2019 Presidential Election}

One of the purposes of a Social Media organized team was the new reality that the impact will provide for voter participation [4]. There were four sections in the new round. First, the opinion leaders as the coordinator of propaganda to search the material and produce content on the search results customized content to target preferences of voters. Content that has been created was shared with buzzers provided in previously owned groups.

Second, the stage of content amplification. Personal account or buzzer shared content such videos, images, and news on social media to got the public attention. Public attention was categorized into two, there were trending topics or specific target groups based on micro information. Third, after the content becomes viral on one social media, the next content would be distributed organically to other social media from small to large scale. Finally, netizens as voters accept the content to check the truth. The content aimed to influence voter behavior.

\section{Political Identity in 2019 Presidential Election}

This research found political identity issues and discourses were used in the 2019 Presidential Election campaign. There were several issues or discourses on political identity used by both camps. One topic that got quite attention from public and rising public issue or discourse initiated by Jokowi's camp to be held "Al Quran-reading test" for both candidates. The issue or discourse of the Al Quran-reading test coincided with the cancellation by the KPU of providing vision and mission because there was no format agreement between the two camps. 
Based on this study, it was estimated that two discussions between the Al Quran-read test conversations with vision and mission. The most dominance was still issued by the vision-mission conversation which was 82,300 mentions, while about the Al Quran-reading test was only 21,200. mentions. Conversations about the Al Quran-reading test got quite high attention, although not as much as the vision-mission conversation.

Next finding was showed from the SNA graph between the two conversations above found that Jokowi's camp had a lot of tweet activities with the theme of the Al Quran-reading test. Prabowo stronghold while giving more attention to the vision and mission. Thus, it can be concluded that the political identity in this case was the Al Quran-reading test initiated quite get the attention of the netizens. The issue or discourse on the Al Quran-reading test was also quite well utilized by the Jokowi faction's social media team to attack Prabowo's camp.

\section{Conclusion}

This study concluded that both camps in the 2019 Presidential Election campaign used Computational Propaganda. In the process of the campaign, issues or discourses on political identity get enough attention from the public. In addition, both camps also detected using bots as a tool for the amplification of certain issues to many social media. Generaly, Computational Propaganda in Indonesia has been detected in social media such as Instagram, Facebook, Twitter, WhatsApp and the subjects user are political parties and the contracting company.

\section{References}

[1] Utomo WP. Menimbang Media Sosial dalam Marketing Politik di Indonesia: Belajar dari Jokowi-Ahok di Pilkada DKI Jakarta 2012. J Ilmu Sos Dan Ilmu Polit 2013;3013:67-84.

[2] Woolley SC, Guilbeault D. Computational Propaganda in the United States of America; Manufacturing Consensus Online. 2017.

[3] Marcuse H. One Dimensional Man. New York: Beacon Press; 1964.

[4] Mahardika MF, Trisliantama A, Tsalitsi MA. Computational Propaganda Dalam Kampanye Pemilihan Presiden 2019. PKM UGM 2019:1-9.

[5] Bolsover G, Howard P. Computational Propaganda and Political Big Data: Moving Toward a More Critical Research Agenda. Oxford Internet Intitute 2017;5:1-4.

[6] Neudert LM. Computational Propaganda in Germany: A Cautionary Tale. 2019.

[7] Sanovich S. Computational Propaganda in Russia: The Origins of Digital Misinformation. 2017.

[8] Bradshaw S, Howard PN. The Global Disinformation Order. Global Inventory of Organised Social Media Manipulation. 2019.

[9] Fahmi I. Membaca Indonesia \#3 Cyber War jelang Reuni 212. Media Kernels 2019:305-21.

[10] Andriadi F. Demokrasi di Tangan Netizen: Tantangan dan Prospek Demokrasi Digital. Jakarta: RM Book; 2016.

[11] Widayanti T. Politik Subaltern: Pergulatan Identitas Waria. Yogyakarta: UGM Press; 2009. 